\title{
KARAKTERISTIK DASAR POPULASI BAKTERI PENAMBAT NITROGEN NON-SIMBIOTIK PADA LAHAN GAMBUT BEKAS KEBAKARAN
}

(Basic characteristics the population of non-simbiotic nitrogen-fixing bacteria on burn peatlands)

\author{
Menik Desmina, Wiwik Ekyastuti, Hanna Artuti Ekamawanti \\ Fakultas Kehutanan Universitas Tanjungpura Pontianak. Jl. Daya Nasional Pontianak 78124 \\ Email: menikdesmina99@gmail.com
}

\begin{abstract}
Nitrogen is an macroessential nutrient for plant growth. Insufficient nitrogen or nitrogen elements, the plant will be upnormal. The availability of nitrogen can be obtained through one of the microbes in the soil, namely nitrogen fixing bacteria (NFB) that is capable of fixing free nitrogen, including symbiotic and non-symbiotic. This study aimd to describe the density of population and the basic characteristics of NFB in burnt peatland Kuala Dua village. The method was in soil sampling with systematic sampling. Bacteria isolation using yeast extract mannitol agar (YEMA) media by using the pour plate method. The density of bacterial population was calculated by count pour method. The result showed tha the higest population density in peat from at distance of $80 \mathrm{~m}$ from the edge of the trench with a depth of 0-20 cm as much $\left(52.10^{7} \mathrm{cfu} / \mathrm{g}\right.$ soil), while a low population density was found at a distance of $20 \mathrm{~m}$ from the edge of a trench with a depth of $20-50 \mathrm{~cm}$ by much $\left(15,5.10^{7} \mathrm{cfu} / \mathrm{g}\right.$ soil). The bacterial population in burnt peatland fall was categorited the high. there potential can developed to support the restoration of peatland ecosystems originating from burnt peatlands.
\end{abstract}

Keywords: charakteristics, burnt peatlands, nitrogen fixing bacteria, restoration.

\section{PENDAHULUAN}

Lahan gambut dikenal sebagai lahan yang rapuh atau rentan dengan perubahan karaktristik yang tidak menguntungkan, sehigga yang menyebabkan produktivitas lahan menurun bahkan menjadi tidak berprduktif (Masganti 2013). Pada dasarnya, lahan yang tidak produktif adalah lahan yang telah mengalami penurunan fungsi atau terdegradasi akibat adanya konversi atau alih guna lahan, kondisi lahan kering atau tidak tergenang dan bekas penebangan (Wahyunto et al. 2013). Degradasi pada lahan gambut bekas kebakaran menyebabkan perubahan pada karakteristik gambut meliputi komponen fisik, kimia dan biologi.Salah satu lahan gambut bekas kebakaran yang ada di Kalimantan Barat berada di desa Kuala Dua bekas kebakaran besar pada tahun 2014. Komponen biologi yang berkurang akibat degradasi yaitu berkurangnya bahkan punah habitat ekosistem satwa dan vegetasi pada lahan gambut. Tidak hanya satwa dan vegetasi tetapi mikrob yang ada di dalam tanah contohnya bakteri dan fungi (Agustina et al. 2001).

Mikrob yang ada didalam tanah dan bermanfaat bagi tanaman adalah bakteri dan fungi. Bakteri yang berperan dalam penambatan nitrogen salah satunya 
adalah bakteri penambat nitrogen (BPN). BPN terbagi menjadi dua golongan yaitu BPN simbiotik yang bersimbiosis dengan tanaman legum dan BPN nonsimbiotik yang hidup bebas pada rizosfer. Menurut Isti' anah 2014 mikrob yang terdapat di dalam tanah memainkan peran penting dalam produktivitas tanaman, terutama dalam penambatan nitrogen dan menghasilkan zat pemacu tumbuh. Peran BPN dapat dikembangkan dan dimanfaatkan sebagai agens hayati untuk membantu restorasi ekosistem lahan gambut terdegradasi. Menurut Nasahi (2010), faktor yang mempengaruhi aktifitas bakteri penambat nitrogen yaitu ketersediaan seyawa $\mathrm{N}$ seperti amonium dan nitrat. Salah satu contoh BPN nonsimbiotik adalah Azotobacter yang paling sering ditemukan pada rizosfer. Bakteri ini berbeda dengan bakteri rizobium karena bakteri ini hidup bebas sehingga tidak memerlukan tanaman inang yang spesifik. Upaya pengembangan potensi BPN dalam mendukung restorasi ekosistem lahan gambut terdegradasi sebagai sumber inokulasi awal, dibutuhkan isolat BPN berasal dari lahan gambut bekas kebakaran. Kebutuhan bakteri akan unsur $\mathrm{N}$ dapat dipenuhi dari sumber $\mathrm{N}$ yang terdapat dalam berbagai senyawa organik maupun dari udara. Penelitian bertujuan untuk mendreskripsikan kepadatan populasi dan karakteristik dasar BPN pada lahan gambut bekas kebakaran dengan kedalaman dan jarak masing-masing dari tepi parit.

\section{METODE PENELITIAN}

\section{Waktu dan Tempat Penelitian}

Penelitian dilaksanakan pada bulan Februari-April 2018. Lokasi pengambilan sampel tanah di desa Kuala Dua Kabupaten Kubu Raya. Isolasi BPN dilakukan di Laboratorim Silvikutur Fakultas Kehutanan Universitas Tanjungpura Pontianak.

\section{Prosedur Penelitian}

Pengambilan sampel tanah gambut

Metode yang digunakan dalam pengambilan sampel adalah metode systematic sampling. Jarak pengambilan sampel tanah gambut pada masingmasing jalur dengan jarak $20 \mathrm{~m}, 50 \mathrm{~m}$, dan $80 \mathrm{~m}$. Masing-masing jarak diambil dengan kedalaman 0-20 cm, dan 20-50 $\mathrm{cm}$ pada setiap jalur. Tanah yang diambil setiap jarak sebanyak $300 \mathrm{~g}$ dan dimasukan kedalam kantong plastik dan beri label sesuai jarak dan kedalaman masing-masing. Tanah dengan kedalaman dan jarak yang sama pada ketiga jalur tersebut, sampel tanahnya kemudian dikompositkan menjadi satu sampel sehingga diperoleh enam sampel tanah dengan berat masing-masing 900 g. Bersamaan pada pengambilan sampel juga melakukan pengukuran iklim lingkungan seperti parameter suhu udara, kelembaban, dan curah hujan.

Isolasi Bakteri Penambat Nitrogen (BPN)

Media selektif isolasi BPN menggunakan yeast extract mannitol agar (YEMA). Sampel bakteri diisolasi dengan metode tuang (pour plate method) pada seri pengenceran $10^{-1}$ sampai $10^{-7}$. Sampel tanah ditimbang sebanyak $10 \mathrm{~g}$ dari masing-masing 
sampel kemudian dimasukan kedalam Erlenmeyer dicampurkan dengan akuades steril hingga $100 \mathrm{ml}$, lalu dihomogenisasi menggunakan vortex. Selanjutnya diambil $1 \mathrm{ml}$ larutan dari Erlenmeyer tadi dimasukan ke dalam microtube berukuran $2 \mathrm{ml}$, kemudian diambil $0,1 \mathrm{ml}$ larutan tanah menggunakan pipet mikro masukan kedalam microtube yang berisi $0,9 \mathrm{ml}$ akuades steril sehingga diperoleh tingkat pengenceran $10^{-1}$. Prosedur tersebut diulang terus sampai dengan seri pengenceran $10^{-7}$. Sampel yang sudah diencerkan dengan metode pengenceran diambil masing-masing dengan cara mengambil $0,1 \mathrm{ml}$ dari pengenceran $10^{-3}, \quad 10^{-5}, \quad 10^{-7}$ menggunakan pipet mikro kemudian dimasukan kedalam cawan Petri secara aseptis yang telah berisi media YEMA lalu ratakan dengan memutar media membentuk angka delapan agar homogen. Bakteri diinkubasi selama 15 hari. Selanjutnya koloni BPN yang terpisah atau membentuk koloni tunggal tidak dempet dengan bakteri lain di murnikan untuk menjadi isolat. Diperoleh 22 isolat yang akan dikarakterisasi morfologi dan diuji fisiologis menggunakan indikator Congo Red (CR) dan Bromthimol Blue (BB).

\section{Perhitungan Kepadatan populasi BPN}

Perhitungan koloni BPN selama 15 hari dimulai dari hari pertama setelah melakukan isolasi BPN. Diamati mulai hari ke-1 sampai dengan hari ke-15 dihitung jumlah koloni yang tumbuh dan beri tanda pada koloni yang tumbuh akan memampakan seperti bercak lendir putih pada media. Penandaan koloni menggunakan pulpen OHP dibagian bawah cawan Petri agar dapat membedakan antara koloni tumbuh baru dan yang sudah terhitung. Koloni yang tumbuh kemudian dimurnikan untuk dikarakteristikkan bagian morfologi untuk mengetahui apakah termasuk BPN rizobia atau bukan. Koloni yang tumbuh dihitung menggunakan metode perhitungan cawan (total plate count/TPC) dengan satuan cfu/g tanah. Kepadatan koloni dihitung menggunakan rumus kepadatan bakteri: jumlah koloni $\mathrm{x} \frac{1}{\text { faktor pengenceran }}$

\section{HASIL DAN PEMBAHASAN}

Berdasarkan hasil penelitian yang telah dilakukan pada 6 sampel tanah gambut dari beberapa jarak dan kedalaman masing-masing ditemukan populasi BPN dengan kepadatan yang bervariasi. Kepadatan rerata koloni BPN yang tumbuh selama 15 hari dilihat pada Gambar 1. 


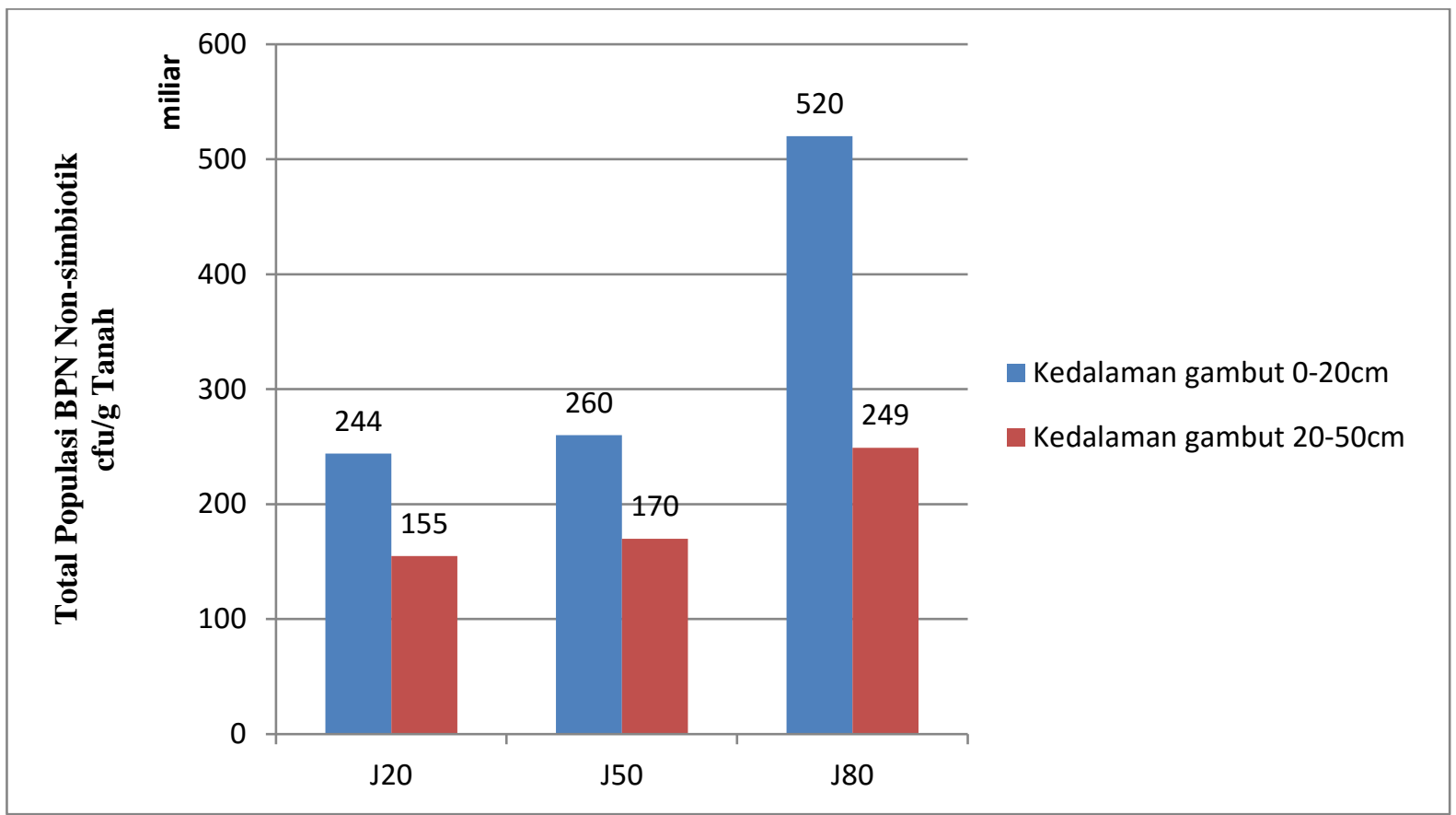

Gambar 1. Kepadatan populasi BPN setelah diinkubasi selama 15 hari.( Population density of NFB after incubation for 15 days.)

Keterangan: J20: Jarak 20 m dari tepi parit, J50: Jarak 50 m dari tepi parit, J80: Jarak 80 m dari tepi parit (meter) K: kedalaman (cm)

Gambar 1 menunjukan jumlah populasi BPN yang bervariasi dengan jarak dan kedalaman masing-masing dari tepi parit. Jumlah koloni BPN pada sampel yang diambil terbilang kategori tinggi, kedalaman 0-20 cm lebih tinggi dari pada jumlah koloni BPN pada kedalaman 20-50 cm. Hal ini karena perakaran tanaman mempengaruhi kehidupan mikrob secara fisiologis yang berada dekat dengan perakaran tanaman lebih aktif dibandingkan dengan yang jauh dari perakaran (Purwaningsih 2004). Tanah rizosfer atau tanah yang dekat dengan perakaran tanaman adalah daerah yang banyak mengandung karbon (C) yang digunakan mikrob untuk melakukan pertumbuhan, salah satunya adalah BPN (Barea 2005).
Perbedaan populasi BPN diperoleh dari sampel yang kondisi fisik dan kimia tanah ( kandungan unsur hara makro seperti N, P, K, P-potensial, P-tersedia dan kadar C-organik) yang berbedabeda. Kedalaman gambut di lokasi lahan gambut bekas kebakaran bekisar 4,6-5,6 m dengan tingkat kematangan gambut dari fibrik hingga hemik (Ekamawanti et al. 2017). Kepadatan populasi tertinggi ditemukan pada jarak $80 \mathrm{~m}$ dengan kandungan unsur haranya termasuk C-organik paling tinggi dibandingkan jarak $50 \mathrm{~m}$ dan $20 \mathrm{~m}$ dari tepi parit. Faktor lain dalam mempengaruhi kepadatan populasi BPN adalah faktor lingkungan seperti suhu, kelembaban dan curah hujan. Suhu udara rata-rata pada bulan Februari saat 
pengambilan sampel tanah sekitar $30^{\circ} \mathrm{C}$, dan kelembapan rata-rata $84 \%$ dengan curah hujan rata-rata $13,4 \mathrm{~mm} / \mathrm{bulan}$. Banya curah hujan 201,7 mm dengan banyak hari hujannya 17 hari dalam sebulan.

Agustian (2012) menemukan populasi BPN pada tanah rizosfer Titonia sekitar $19,7.10^{3} \mathrm{cfu} / \mathrm{g}$ tanah,

Karakteristik morfologi untuk mengetahui bakteri secara makroskopis dari segi bentuk, warna, permukaan, tepian dan elevasinya. Dari 6 sampel tanah gambut berhasil ditemukan 22 isolat BPN dengan karakteristik morfologi yang berbeda.

Isolat yang berbeda pada sampel tanah memiliki karakteristik berbeda-beda karena berasal dari koloni BPN yang yang berbeda. Hasil karakteristik morfologi ditemukan 13 isolat yang termasuk rizobia dan 9 isolat yang nonrizobia. Ternyata bakteri rizobia mendominasi pada lahan gambut bekas kebakaran karena pada lahan gambut tersebut banyak perakaran tanaman pionir dan beberapa vegetasi seperti akasia yang memungkinkan ketersediaan substrat dan suplai makanan bagi bakteri.

Karakteristik fisiologis BPN

Karakteristik fisiologis yang dilakukan untuk mengkarakterisasi bakteri tersebut termasuk bakteri rizobia atau bukan dan merupakan rangkaian kegiatan identifikasi BPN. Karakteristik fisiologi menggunakan indikator Congo Red (CR) untuk melihat apakah bakteri menyerap merah kongo atau tidak dan Bromthimol Blue (BB) untuk melihat sedangkan pada lahan gambut pertanian yang subur mengandung lebih dari $1.10^{4} \mathrm{cfu} / \mathrm{g}$ tanah (Tate 2000). Berdasarkan pernyataan tersebut kepadatan populasi BPN pada lokasi penelitian termasuk tinggi, yaitu sebesar $15,5.10^{7} \mathrm{cfu} / \mathrm{g}$ tanah sampai dengan $52.10^{7} \mathrm{cfu} / \mathrm{g}$ tanah (Gambar 1).

\section{Karakteristik morfologi BPN}

bakteri bereaksi asam akan berwarna kuning atau tidak.

Hasil dari karakteristik fisiologis BPN ditemukan 13 isolat yang termasuk dalam rizobia. Hasil menyatakan terdapat banyak bakteri rizobia dan nereaksi masam, namum belum jelas dari segi jenis BPN yang spesifik karena hanya dasar karakteristik BPN. Untuk itu perlu penelitian lanjut untuk mengidentifikasi jenis BPN yang lebih spesifik.

\section{KESIMPULAN}

Pada gambut bekas kebakaran berada di Desa Kuala Dua, ditemukan populasi yang bervariasi pada jarak dan kedalaman yang berbeda terdapat kecendrungan dari tepi parit semakin jauh semakin besar. Populasi BPN bervariasi ditemukan dari sampel tanah pada jarak $80 \mathrm{~m}$ dari tepi parit, kemudian diikuti pada jarak $50 \mathrm{~m}$ dari tepi parit dan yang paling sedikit ditemukan pada jarak $20 \mathrm{~m}$ dari tepi parit pada kedalaman yang sama yaitu 0-20 cm. Karakteristik morfologi BPN ditemukan isolat berbeda-beda yang termasuk rizobia dan 9 isolat yang nonrizobia berdasarkan hsil karakterisasi morfologi dan uji fisiologis $\mathrm{BPN}$. 


\section{SARAN}

Populasi BPN pada lahan gambut bekas kebakaran dengan jarak dan kedalaman masing-masing berbedabeda, namum diperlukan penelitiaan lanjut yang spesifik untuk mengetahui jenis BPN yang terdapat pada lahan gambut bekas kebakaran.

\section{UCAPAN TERIMAKASIH}

Terimakasih kepada SEAMEO BIOTROP melalui Dr. Hanna Artuti Ekamawanti (sebagai ketua peneliti) telah membantu dana penelitian ini dari DIPA Biotrop 2017 yang berjudul "Pengembangan Sistem Paludikultur untuk Lahan Gambut dan Teknik Propagasi Tumbuhan Indigenos".

DAFTAR PUSTAKA

Agustian, Syaifei R, Maira L. 2012. Keragaman Bakteri Penambat N Pada Tanah Rhizosfir Titonia Pada Tanah Masam Ultisol. Jurnal Solum. 9(2) : 98-105.
Barea JM. Pozo M.J. 2005. Microbial Cooperation In The Rhizozphere. Jurnal of exp. Botany.56(2): 1761-1778.

Ekamawanti HA, Tata MHL, Astiani D, Ektastuti W. 2017. Pengembangan Sistem Paludikultur Untuk Restorasi Lahan Gambut Terdegradasi: Karakterisasi Lahan Gambut Dan Teknik Propagasi Jenis Tumbuhan Indigenus. Laporan DIPA Biotrop 2017. Pontianak.

Masganti, Wahyunto, Dariah A, Nurhayati, Yusuf R. 2013. Karakteristik dan potensi pemanfaatan lahan gambut terdegradasi di Provinsi Riau. Jurnal sumber daya lahan. 8(1): 59-66.

Purwaningsih S. 2004. Isolasi, Populasi dan Karakterisasi Bakteri pada tanah dari Taman Nasional Bogani. Sulawesi Utara. Biologi 3(1): 22-34. 